\title{
High PD-L1 expression is associated with stage IV disease and poorer overall survival in 186 cases of small cell lung cancers
}

\author{
Yih-Leong Chang ${ }^{1,3}$, Ching-Yao Yang ${ }^{2,3, *}$, Yen-Lin Huang ${ }^{1, *}$, Chen-Tu Wu1,3, Pan- \\ Chyr Yang ${ }^{2,3,4}$ \\ ${ }^{1}$ Department of Pathology, National Taiwan University Hospital and National Taiwan University College of Medicine, Taipei \\ 10002, Taiwan \\ ${ }^{2}$ Department of Internal Medicine, National Taiwan University Hospital and National Taiwan University College of Medicine, \\ Taipei 10002, Taiwan \\ ${ }^{3}$ Graduate Institute of Pathology, National Taiwan University College of Medicine, Taipei 10002, Taiwan \\ ${ }^{4}$ National Taiwan University, Taipei 10617, Taiwan \\ *These authors have contributed equally to this work \\ Correspondence to: Chen-Tu WU, email: ipohdamu@gmail.com
}

Keywords: small cell lung cancer, immunotherapy, programmed cell-death ligand 1, stage, overall survival

Received: October 06, $2016 \quad$ Accepted: December 27, 2016 Published: February 01, 2017

\section{ABSTRACT}

Background: Small cell lung cancer (SCLC) is an aggressive malignancy with a distinct natural history and dismal prognosis. SCLC is characterized as a recalcitrant neoplasm with limited therapeutic options and platinum-based chemotherapy is the treatment of choice. Programmed cell death-ligand 1(PD-L1)-mediated immune escape may be a suitable target for specific therapy, but its role in SCLC is unclear.

Materials and methods: In total, 186 SCLC cases were investigated. Paraffinembedded tumor sections were stained with a PD-L1 antibody. PD-L1 overexpression was denoted by moderate-to-strong PD-L1 membrane staining in $\mathbf{2} \mathbf{5 \%}$ of tumor cells. Tumor cells and infiltrating lymphocytes were scored separately.

Results: The overall frequency of PD-L1 overexpression, in tumor cells and tumor infiltrating lymphocytes (TILs) was $\mathbf{7 8 . 0 \%}$ and $\mathbf{5 4 . 3 \%}$, respectively. High tumor PDL1 expression was significantly correlated with high TIL PD-L1 expression $(P=0.001)$ and stage IV disease $(P=0.048)$. Multivariate analysis revealed that high tumor $P D-L 1$ expression and stage IV disease were two independent risk factors for poor overall survival.

Conclusions: High PD-L1 expression was observed in SCLCs compared with their expression in conventional NSCLCs. The aggressive behavior of SCLC could be partially related to PD-L1-mediated immune escape. High PD-L1 expression correlated with poor prognosis and may provide a rationale for immunotherapy for high-grade SCLC.

\section{INTRODUCTION}

Small cell lung cancer (SCLC) is an aggressive neuroendocrine cancer that secretes and responds to a wide variety of mitogenic peptide growth factors, SCLC accounts for $10-20 \%$ of all lung cancers [1]. It displays a distinct natural history with a high proliferative index and an unusually strong predilection for early metastasis [2]. These tumors are very sensitive to chemotherapy and radiotherapy, but are characterized by the relatively rapid appearance of chemo/radioresistance and relapses are common. The five-year survival is approximately $20-25 \%$ for stage I-III disease, in which the tumor is confined to one hemithorax, and $5 \%$ for stage IV disease, in which the tumor has metastasized beyond one hemithorax [3]. The development of systemic therapeutics over the past 10 years has been disappointing. Therefore, there is a clear need to find new therapeutic strategies to treat SCLC.

Programmed cell death ligand 1 (PD-L1) couples with programmed cell death 1 (PD-1), a coinhibitory receptor on T-cells, to play an important role in the ability of tumor cells to evade the host immune system [4]. In theory, tumor cells that overexpress PD-L1 have the capacity for "immune escape", which can result in 
aggressive behavior. In fact, it has been reported that PD-L1 overexpression in tumor cells is related to worse disease control and treatment outcomes in many other types of cancer $[5,6]$. Recently, clinical trials using monoclonal antibodies targeting the PD-1/PD-L1 axis have shown promising antitumor activity in several malignancies, including lung carcinomas. Preliminary data from these trials suggest that tumor PD-L1 expression may predict response to such treatments $[7,8]$. In the context of clinical trials, PD-L1 protein expression on tumor cells, as detected by immunohistochemistry is currently the best predictive biomarker $[7,8,9]$.

The goal of this study was to conduct a comprehensive investigation of PD-L1 expression in a large series of patients with SCLC and to correlate the expression with clinicopathologic parameters and clinical outcomes.

\section{RESULTS}

\section{Patient demographics}

One-hundred-sixty-seven $(89.8 \%)$ of the patients were men, and $19(10.2 \%)$ patients were women (Table $1)$. One-hundred-sixty (86\%) patients were smokers. The mean age at diagnosis was 67.1 years (range, 36-89 years). The distribution of SCLC stage among the patients was as follows: stage I-III disease, 74 patients $(39.8 \%)$ and stage IV disease, 112 patients (60.2\%) (Table 1). One hundred forty-six patients received chemotherapy, radiotherapy, or combination chemoradiotherapy. Most of the patients died of disease. One hundred one patients (54.3\%) experienced paraneoplastic syndrome (PNS), which presented as hyponatremia $(50.5 \%)$, hypokalemia $(4.3 \%)$, hyperkalemia $(3.7 \%)$, hyperlipidemia $(0.5 \%)$ or hypomagnesiumia $(0.5 \%)$. The serum LDH level was higher than the upper normal limit of normal in 98 patients $(52.7 \%)$, whereas the high serum CEA levels were noted in 56 patients $(30.1 \%)$.

Interestingly, the tumor location in the patients with SCLC had a higher propensity for the left upper lobe $(36.0 \%)$, followed by the right upper lobe $(23.7 \%)$. The distribution of tumors in the left lower lobe, right middle lobe and right lower lobe was the same: $13.4 \%$ each.

Given the very limited role of surgery in SCLC, most materials were collected via biopsies, including: bronchoscopic biopsy $(125 / 186,67.2 \%)$, sonographyguided biopsy $(30 / 186,16.1 \%)$ or CT-guided biopsy $(22 / 186,11.8 \%)$. Only a few patients underwent surgery: lobectomy $(6 / 186,3.2 \%)$ or wedge resection $(3 / 186$, $1.6 \%)$.

In the histological analysis, the tumors were characterized by small cells with scant cytoplasm, poorly defined cell borders, finely dispersed granular nuclear chromatin, and absent or inconspicuous nucleoli. The cells were round, oval, or spindle-shaped (Figure 1A).
In the 103 tumors of 186 patients (55.4\%), necrosis/brisk apoptotic activity was noted (Figure 1B).

\section{Analysis of PD-L1 expression}

Immunostaining for PD-L1 was observed in the membrane of the tumor cells and stromal lymphocytes. Tumor PD-L1 membranous reactivity (Figure 2A) was detected in 145 of the 186 patients $(78.0 \%)$. There were also PD-L1-positive monocytic cells (Figure 2B) in the adjacent stroma. These cells were immunoreactive to the common leukocyte IHC marker CD45 (Figure 2C) and the T-cell marker CD3 (Figure 2D), while negative for the macrophage marker CD68 (Figure 2E) and were considered tumor-associated lymphocytes (TILs). Varying numbers of TILs were noted and 101/186 cases (54.3\%) showed PD-L1-positive TILs. The staining intensity was usually moderate to strong similar to what was observed in the tumor cells. The TILs were frequently located at the interface between carcinoma cells and the stroma, with occasional infiltration within the carcinoma cells.

\section{Correlations of PD-L1 expression with clinicopathologic features and survival}

High PD-L1 expression was associated with advanced age $(\geq 60$ years $)(\mathrm{P}<0.001)$ and $\mathrm{PD}-\mathrm{L} 1$ expression in TILs $(\mathrm{P}=0.001)$ (Table 1$)$.

Survival analysis using a Kaplan-Meier plots and log-rank tests identified three significant risk factors for poor overall survival: advanced age $(\mathrm{P}=0.001)$, stage IV diaease $(\mathrm{P}<0.001)$ and positive tumor $\mathrm{PD}-\mathrm{L} 1$ expression $(\mathrm{P}<0.001)$ (Table 2). In the multivariate analysis, stage IV disease (Figure 3A) and positive tumor PD-L1 expression (Figure 3B) were significantly associated with poor overall survival (Table 3).

\section{DISCUSSION}

SCLC is a heterogeneous and genetically complex disease with a very high mortality rate. The current standard of care includes concurrent chemoradiation with cisplatin and etoposide for stage I-III disease SCLC and a combination of platinum and etoposide or irinotecan for stage IV disease SCLC [13]. Despite the high chemosensitivity of these tumors, $>90 \%$ of patients with metastatic disease will experience disease relapse after a response and there are limited therapeutic options for these patients. Furthermore, despite therapeutic progress, the clinical benefit of new targeted therapies has been disappointing in SCLC [14]. The etiology and molecular events associated with this disease are mostly unknown. There are presently no available data indicating the optimal management of patients with SCLC.

For the past few decades, the choices for the systemic disease control of SCLC have been limited. 
Table 1: Characteristics of patients, PD-L1 expressions and clinicopathologic parameters

\begin{tabular}{|c|c|c|c|c|c|c|c|}
\hline \multirow{2}{*}{ Variable } & \multirow{2}{*}{ Total } & \multicolumn{2}{|c|}{ Tumor PD-L1 expression } & \multirow{2}{*}{ P Value } & \multicolumn{2}{|c|}{ TIL PD-L1 expression } & \multirow{2}{*}{ P Value } \\
\hline & & Positive & Negative & & Positive & Negative & \\
\hline Patient number & 186 & $145(78.0 \%)$ & $\begin{array}{c}41 \\
(22.0 \%)\end{array}$ & & $101(54.3 \%)$ & $85(45.7 \%)$ & \\
\hline \multicolumn{8}{|l|}{ Age (year) } \\
\hline$<60$ & 49 & 29 & 20 & & 24 & 25 & \\
\hline$\geq 60$ & 137 & 116 & 21 & $<0.001$ & 77 & 60 & 0.407 \\
\hline \multicolumn{8}{|l|}{ Sex } \\
\hline Male & 167 & 132 & 35 & & 91 & 76 & \\
\hline Female & 19 & 13 & 6 & 0.379 & 10 & 9 & 1.000 \\
\hline \multicolumn{8}{|l|}{ Smoking status* } \\
\hline Smoker & 160 & 126 & 34 & & 90 & 70 & \\
\hline Nonsmoker & 13 & 12 & 1 & 0.471 & 8 & 5 & 0.779 \\
\hline \multicolumn{8}{|l|}{ Necrosis } \\
\hline$\geq 20 \%$ & 53 & 40 & 13 & & 27 & 26 & \\
\hline$<20 \%$ & 133 & 105 & 28 & 0.695 & 74 & 59 & 0.626 \\
\hline \multicolumn{8}{|l|}{ Stage } \\
\hline Stage I-III & 74 & 52 & 22 & & 39 & 35 & \\
\hline Stage IV & 112 & 93 & 19 & 0.048 & 62 & 50 & 0.765 \\
\hline \multicolumn{8}{|l|}{ PNS } \\
\hline Positive & 101 & 81 & 20 & & 60 & 41 & \\
\hline Negative & 85 & 64 & 21 & 0.479 & 41 & 44 & 0.141 \\
\hline \multicolumn{8}{|c|}{ Serum LDH level } \\
\hline Normal & 88 & 68 & 20 & & 43 & 45 & \\
\hline Abnormal & 98 & 77 & 21 & 0.861 & 58 & 40 & 0.185 \\
\hline \multicolumn{8}{|c|}{ Serum CEA level } \\
\hline Normal & 130 & 101 & 29 & & 67 & 63 & \\
\hline Abnormal & 56 & 44 & 12 & 1.000 & 34 & 22 & 0.266 \\
\hline \multicolumn{8}{|l|}{$\begin{array}{l}\text { Tumor PD-L1 } \\
\text { expression }\end{array}$} \\
\hline Positive & 145 & & & & 88 & 57 & \\
\hline Negative & 41 & & & & 13 & 28 & 0.001 \\
\hline \multicolumn{8}{|c|}{ TIL PD-L1 expression } \\
\hline Positive & 101 & 88 & 13 & & & & \\
\hline Negative & 85 & 57 & 28 & 0.001 & & & \\
\hline
\end{tabular}

*No information in some of the patients.

Abbreviations: PNS, paraneoplastic syndrome; PD-L1, programmed cell death ligand 1; TIL, tumor-infiltrating lymphocytes. 
Recently, many clinical trials have reported that PD-L1 blockade provides durable tumor control with minimalrelated adverse events $[7,8]$. The overexpression of PD$\mathrm{L} 1$, as defined by IHC, in tumor cell membranes is one of the predictive biomarkers noted by previous studies $[6,9,16-22]$. Patients with positive PD-L1 expression in tumor cells have experienced improved clinical outcomes following anti-PD-L1-directed therapy [15, 23]. The recent phase III clinical trials of nivolumab documented that tumor PD-L1 expression could predict treatment response in non-squamous NSCLC [24] but not squamous cell carcinoma [25].

Contradictory to the results reported by Schulthesis et al., 145 of 186 cases $(78.0 \%)$ of SCLC in this series showed positive membranous PD-L1 staining in tumor cells. Our results of frequent PD-L1 expression in SCLC are supported by two recent studies by Ishii et al [20]. and Komiya $\mathrm{T}$, et al [22].

The reasons for the discrepancies among studies are unclear but may include the following: sample collection, methodology for tissue fixation, different antibodies, cutoff points and scoring methods. The cut-off value for PD-L1 positivity is a concern when interpreting the study results. IHC testing has yet to be standardized and optimal IHC assays have not been validated. The IHC antibody we used was also utilized in several studies on various neoplasms, including lymphoma, [27] lung cancer, [6, 16, $19,28,29]$ and head and neck cancer [17]. The cut-off

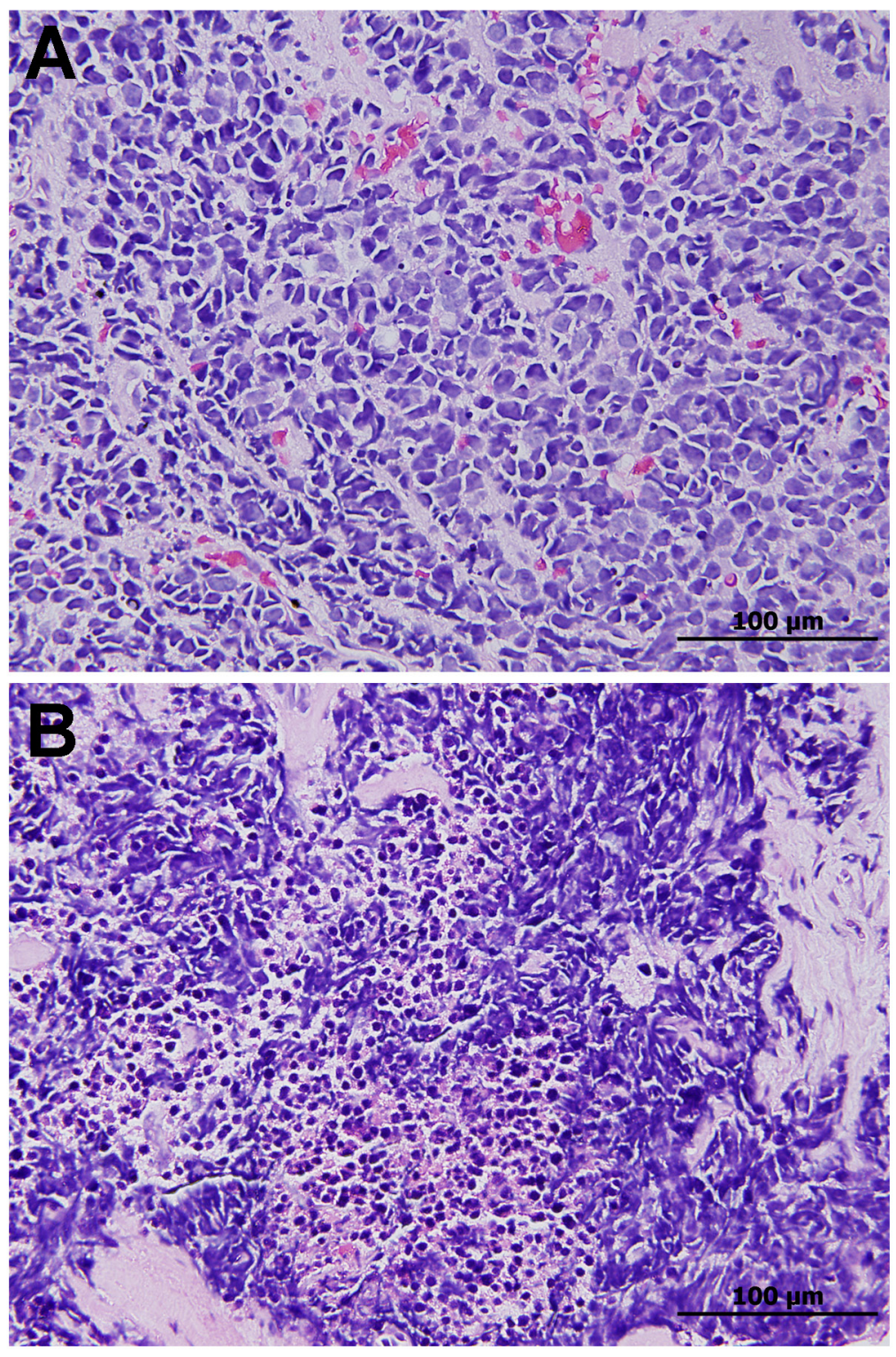

Figure 1: A. Small cell lung carcinoma composed of densely packed small tumor cells with scant cytoplasm, finely granular nuclear chromatin, and inconspicuous nucleoli. B. Necrosis and brisk apoptotic activity are common. 
value of 5\% seemed to be a reasonable threshold for PDL1 expression with our IHC antibody.

Our study revealed that tumor PD-L1 expression and a stage IV disease were significantly associated with poorer prognosis independent of the other factors examined. This result corresponds with previous studies showing that PD-L1 is associated with poorer prognosis in patients with NSCLC, $[6,30]$ esophageal carcinoma, [31] gastric carcinoma, [32] pancreatic carcinoma, [33] hepatocellular carcinoma, [34] renal cell carcinoma, [11]
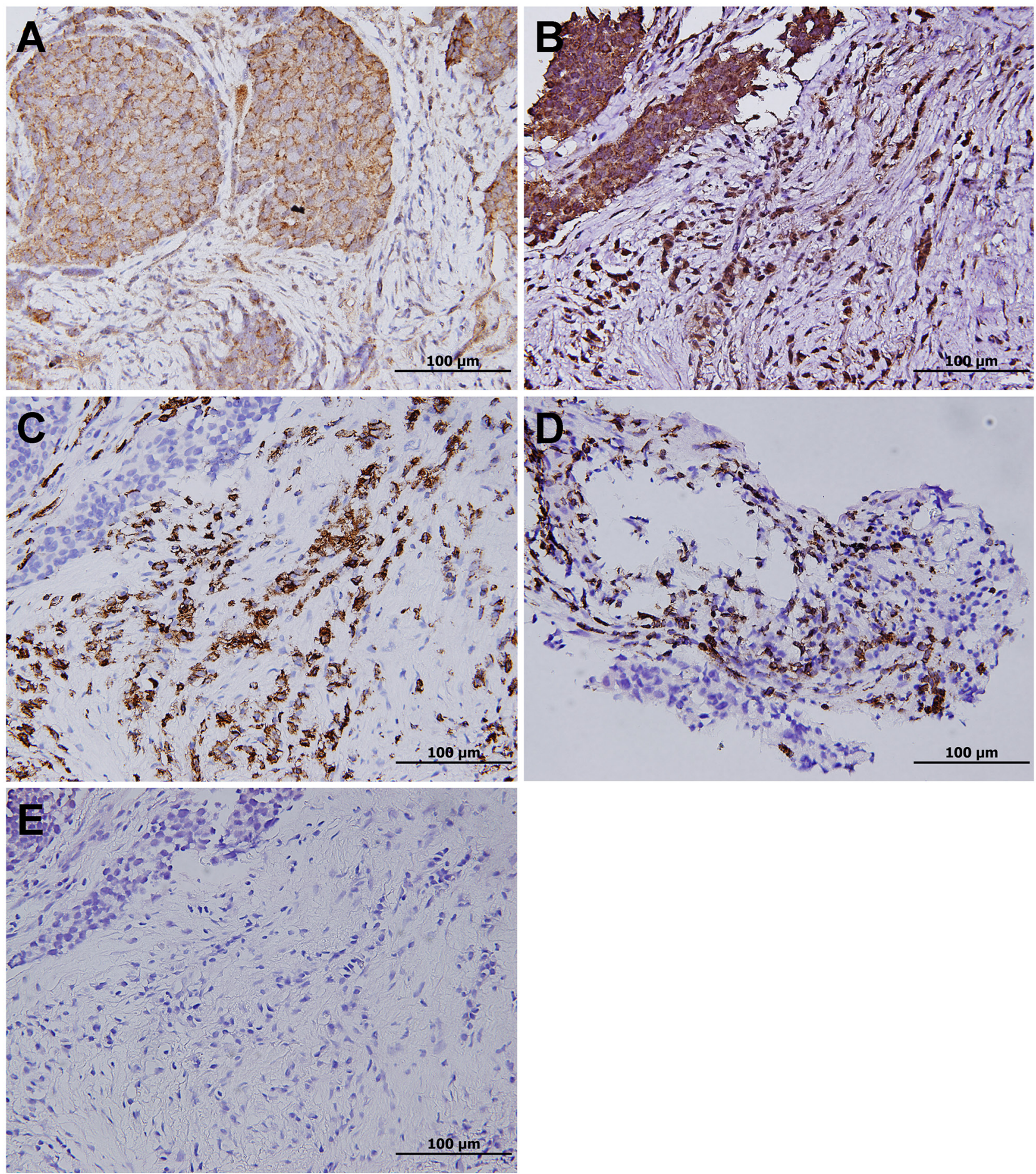

Figure 2: A. Positive PD-L1 immunohistochemical staining with a membranous pattern in small cell lung carcinoma. B. Besides, PD-L1 is expressed in tumor-associated lymphocytes, which stain positive for C. CD45 and D. the T-cell marker CD3, while negative for E. the macrophage marker CD68. 
Table 2: Correlation between clinicopathologic factors and survival in patients with small cell lung cancer

\begin{tabular}{|c|c|c|c|}
\hline Variables & Patient no. & No. of deaths (\%) / 5-year OS (\%) & $p$ value \\
\hline Patient number & 186 & $125(67.2) / 19.8$ & \\
\hline \multicolumn{4}{|l|}{ Age (year) } \\
\hline$<60$ & 49 & $24(49.0) / 42.6$ & 0.001 \\
\hline$\geq 60$ & 137 & $101(73.7) / 12.9$ & \\
\hline \multicolumn{4}{|l|}{ Sex } \\
\hline Male & 167 & $114(68.3) / 18.8$ & 0.392 \\
\hline Female & 19 & $11(57.9) / 23.7$ & \\
\hline \multicolumn{4}{|l|}{ Smoking status* } \\
\hline Smoker & 160 & $107(66.9) / 18.0$ & 0.385 \\
\hline Nonsmoker & 13 & $7(53.8) / 34.2$ & \\
\hline \multicolumn{4}{|l|}{ Necrosis } \\
\hline$\geq 20 \%$ & 53 & $36(67.9) / 16.8$ & 0.636 \\
\hline$<20 \%$ & 133 & $89(66.9) / 21.0$ & \\
\hline \multicolumn{4}{|l|}{ Stage } \\
\hline Stage IV & 112 & $86(76.8) / 7.2$ & $<0.001$ \\
\hline Stage I-III & 74 & $39(52.7) / 35.7$ & \\
\hline \multicolumn{4}{|l|}{ PNS } \\
\hline Positive & 101 & $68(67.3) / 13.8$ & 0.791 \\
\hline Negative & 85 & $57(67.1) / 24.2$ & \\
\hline \multicolumn{4}{|l|}{ Serum LDH level } \\
\hline Normal & 88 & $60(68.2) / 23.0$ & 0.476 \\
\hline Abnormal & 98 & $65(66.3) / 17.0$ & \\
\hline \multicolumn{4}{|l|}{ Serum CEA level } \\
\hline Normal & 130 & $89(68.5) / 20.2$ & 0.647 \\
\hline Abnormal & 56 & $36(64.3) / 19.6$ & \\
\hline \multicolumn{4}{|c|}{ Tumor PD-L1 expression } \\
\hline Positive & 145 & $117(80.7) / 8.2$ & $<0.001$ \\
\hline Negative & 41 & $8(19.5) / 79.6$ & \\
\hline \multicolumn{4}{|c|}{ TIL PD-L1 expression } \\
\hline Positive & 101 & $65(64.4) / 17.5$ & 0.977 \\
\hline Negative & 85 & $60(70.6) / 22.5$ & \\
\hline
\end{tabular}

*No information in some of the patients.

Abbreviations: PNS, paraneoplastic syndrome; PD-L1, programmed cell death ligand 1; TIL, tumor-infiltrating lymphocytes.

and ovarian carcinoma [35]. In contrast to our study, several previous studies reported that PD-L1 expression was associated with better prognosis in patients with NSCLC, [16, 28] SCLC, [20] breast cancer, [36] and malignant melanoma [37]. This discrepancy between the present study and these previous studies may be due to a number of reasons. First, the baseline characteristics of the lung cancer cases included in these studies are heterogeneous and the differences in PD-L1 expression in tumors with dissimilar histology or pathological stage may 
affect the outcome analysis. Second, the threshold for PDL1 expression positivity has not been clearly defined, and reproducibility has not been formally assessed. Third, the techniques and detailed protocol may differ among these studies. For future clinical applications, further efforts to standardize a protocol for ascertaining PD-L1 expression are warranted.

PD-L1 staining on immune cells in lung cancer has been reported in a few studies $[9,15,20,21]$ with the prevalence ranging from $26-53 \%$. In the present study, we found that $54.3 \%$ of cases showed PD-L1 expression in TILs. Recent studies demonstrated that the best clinical tumor responses to anti-PD-L1 therapy were associated with PD-L1 expression in tumor-infiltrating immune cells $[15,26]$. Taken together, frequent PD-L1 expression in either tumor or immune cells in SCLC indicates that targeting the PD-1 axis holds a promise for the clinical treatment of SCLC.
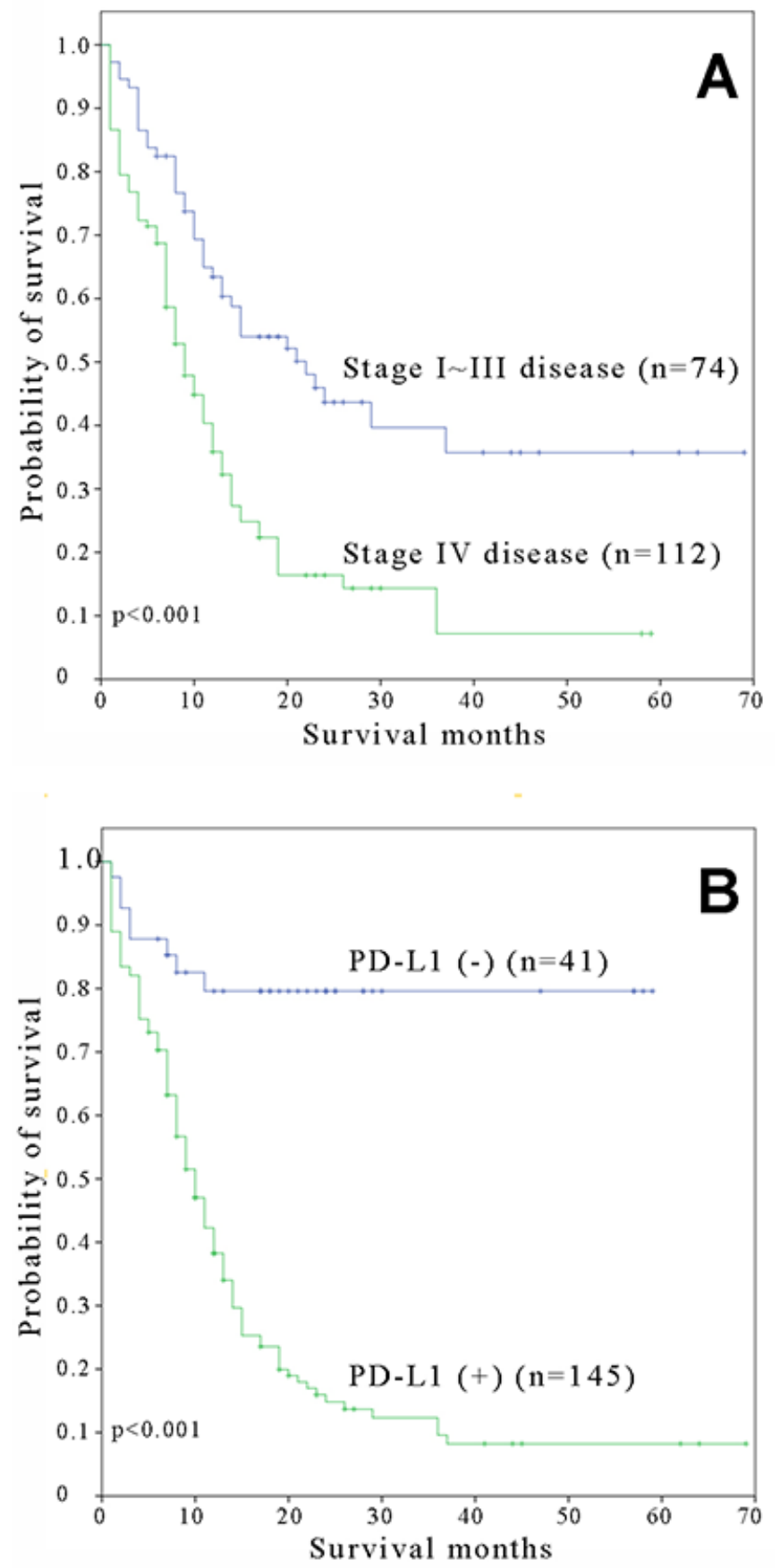

Figure 3: Kaplan-Meier overall survival curves for small cell lung carcinoma patients with A. stage I-III and stage IV and B. positive and negative expressions of PD-L1. 
Table 3: Multivariate survival analysis of clinicopathologic features in patients with small cell lung cancer

\begin{tabular}{lccc}
\hline \multirow{2}{*}{ Variables } & \multicolumn{3}{c}{ Overall survival } \\
\cline { 2 - 4 } Stage & HR & 95\% CI & \\
$\quad$ Stage IV & 1.000 & & \\
$\quad$ Stage I-III & 0.476 & $0.322 \sim 0.703$ & \\
Tumor PD-L1 expression & & & \\
$\quad$ Positive & 1.000 & 0.001 \\
$\quad$ Negative & 0.168 & $0.081 \sim 0.345$ & $<0.001$ \\
\hline
\end{tabular}

Abbreviations: PD-L1, programmed cell death-ligand 1.

SCLC has long been associated with PNS. Endocrine paraneoplastic disorders are characterized by ectopic production of peptide hormones and the neurological complications are related to antibody-mediated damage to the central nervous system. Hyponatremia is the most common PNS (up to 15\%) [14] but the incidence was much higher $(54.3 \%)$ in our series. It might be sensible to screen for SCLC-associated autoantibodies in possible clinical trials to reduce the risk of adverse events.

In conclusion, this large cohort study demonstrates that tumor PD-L1 expression in a membranous pattern is a common feature in SCLC, supporting the hypothesis that PD-L1 expression might lead to enhanced immune evasion by the tumor. High tumor PD-L1 expression was significantly correlated with TIL PD-L1 expression and stage IV disease. In addition, patients with positive PD-L1 expression had a poor clinical outcome. The results also indicate that clinical trials targeting PD-1 and/or PD-L1 may benefit patients with this otherwise difficult to treat disease, and the utility of such targeted therapeutics in clinical practice needs to be determined in randomized trials.

\section{MATERIALS AND METHODS}

\section{Patient populations}

The investigations were performed in a cohort of 186 individuals with SCLC, who were treated at the National Taiwan University Hospital between $1^{\text {st }}$ January 2010 and $31^{\text {st }}$ December 2015. The Hospital's Research Ethics Committee approved the study, and all the patients provided written informed consent. SCLCs was diagnosed according to the criteria set by the World Health Organisation [10]. Morphologic features were evaluated using hematoxylin and eosin-stained sections, and standard immunohistochemical (IHC) markers, such as neuroendocrine markers (chromogranin A, synaptophysin, and CD56), cytokeratins (pancytokeratin AE1/AE3 or CK7), Ki-67 and TTF-1 were analyzed.
Clinical data were tabulated from each patient's medical records and analyzed in conjunction with microscopic findings. The tumor samples used for IHC analysis included surgically resected specimens, bronchoscopy tissue and sonography or computed tomography (CT)-guided lung biopsy tissue from inoperable patients.

\section{Immunohistochemical analysis}

For IHC staining of PD-L1 expression in tumor tissue, 4- $\mu \mathrm{m}$-thick sections from each formalin-fixed, paraffin-embedded tissue blocks were de-waxed with xylene and rehydrated in a graded series of ethanol. For PD-L1 (a rabbit PD-L1 polyclonal antibody which has been used in several previous studies) $[6,16,17,19,27$, 28, 29] Proteintech group Inc., Chicago, IL, USA. The sections were incubated with the PD-L1 antibody (1:250 dilution) for $1 \mathrm{~h}$, and antigen retrieval was performed by autoclaving for $9 \mathrm{~min}$ at $121^{\circ} \mathrm{C}$ in citrate buffer, $\mathrm{pH}$ 6.0. The UltraVision Quanto Detection System HRP DAB (Thermo Fisher Scientific, Fremont, CA, USA) was used according to the manufacturer's instructions. The sections were counterstained with hematoxylin and then mounted.

PD-L1 immunostaining results were classified into two groups according to the intensity and extent of staining: (1) negative, no staining or staining detected in $<5 \%$ of the cells; and (2) positive, when membranous staining was present in $\geq 5 \%$ of the cells and the staining intensity was moderate to strong. The $5 \%$ threshold was based on a previous phase 1 trial of anti-PD-1 agents and studies of other malignances $[8,11,12]$. Two independent pathologists (C-T. W. and Y-L. C.) assessed PD-L1 expression.

\section{Statistical analysis}

The correlation was correlated with various clinicopathologic parameters using Fisher's exact test. Overall survival (OS) was assessed using the Kaplan- 
Meier method, and the log-rank test was used for comparisons. Prognostic factors of OS were analyzed by univariate and multivariate analyses. Hazard ratios and $95 \%$ confidence intervals were calculated for all variables in the regression model. All tests were two sided, and P $<0.05$ was considered significant. PASW Statistics 18.0 (IBM Corporation, Armonk, NY, USA) was used for all the analyses.

\section{ACKNOWLEDGMENTS}

The authors would like to thank Ms. Chih-Hsin Chen for her skillful technical support and Mr. Wen-Chen $\mathrm{Wu}$ for his help with document preparation.

\section{CONFLICTS OF INTEREST}

The authors declare no conflicts of interest.

\section{ROLE OF THE FUNDING SOURCES}

This study is funded by the National Taiwan University Hospital, Taipei, Taiwan (NTUH 105-S2939, NTUH 106-S3342, NTUH 106-S3343).

\section{REFERENCES}

1. Ferlay J, Autier P, Boniol M, Heanue M, Colombet M, Boyle P. Estimates of the cancer incidence and mortality in Europe in 2006. Ann Oncol. 2007; 18:581-92.

2. Rudin CM, Durinck S, Stawiski EW, Poirier JT, Modrusan Z, Shames DS, Bergbower EA, Guan Y, Shin J, Guillory J, Rivers CS, Foo CK, Bhatt D, et al. Comprehensive genomic analysis identifies SOX2 as a frequently amplified gene in small-cell lung cancer. Nature Genetics. 2012; 44:1111-6.

3. Sorensen M, Pijls-Johannesma M, Felip E; on behalf of the ESMO Guidelines Working Group. Small-cell-lung cancer: ESMO clinical practice guidelines for diagnosis, treatment and follow up. Ann Oncol. 2010; 21:V120-5.

4. Dong H, Strome SE, Salomao DR, Tamura H, Hirano F, Flies DB, Roche PC, Lu J, Zhu G, Tamada K, Lennon VA, Celis E, Chen L. Tumor-associated B7-H1 promotes T-cell apoptosis: a potential mechanism of immune evasion. Nat Med. 2002; 8:793-800.

5. Wang A, Wang HY, Liu Y, Zhao MC, Zhang HJ, Lu ZY, Fang YC, Chen XF, Liu GT. The prognostic value of PD-L1 expression for non-small cell lung cancer patients: a metaanalysis. Eur J Surg Oncol. 2015; 41:450-6.

6. Chang YL, Yang CY, Lin MW, Wu CT, Yang PC. High co-expression of PD-L1 and HIF-1 $\alpha$ correlates with tumour necrosis in pulmonary pleomorphic carcinoma. Eur $\mathrm{J}$ Cancer. 2016; 60:125-35.

7. Brahmer JR, Tykodi SS, Chow LQ, Hwu WJ, Topalian SL, Hwu P, Drake CG, Camacho LH, Kauh J, Odunsi K, Pitot HC, Hamid O, Bhatia S, et al. Safety and activity of
anti-PD-L1 antibody in patients with advanced cancer. N Engl J Med. 2012; 366:2455-65.

8. Topalian SL, Hodi FS, Brahmer JR, Gettinger SN, Smith DC, McDermott DF, Powderly JD, Carvajal RD, Sosman JA, Atkins MB, Leming PD, Spigel DR, Antonia SJ, et al. Safety, activity, and immune correlates of anti-PD-1 antibody in cancer. N Engl J Med. 2012; 366:2443-54.

9. Taube JM, Klein A, Brahmer JR, Xu H, Pan X, Kim JH, Chen L, Pardoll DM, Topalian SL, Anders RA. Association of PD-1, PD-1 ligands, and other features of the tumor immune microenvironment with response to anti-PD-1 therapy. Clin Cancer Res. 2014; 20:5064-74.

10. Travis WD. Update on small cell carcinoma and its differentiation from squamous cell carcinoma and other non-small cell carcinomas. Mod Pathol. 2012; 25:S18-30.

11. Thompson RH, Kuntz SM, Leibovich BC, Dong H, Lohse CM, Webster WS, Sengupta S, Frank I, Parker AS, Zincke H, Blute ML, Sebo TJ, Cheville JC, et al. Tumor B7-H1 is associated with poor prognosis in renal cell carcinoma patients with long-term follow-up. Cancer Res. 2006; 66:3381-5.

12. Taube JM, Anders RA, Young GD, Xu H, Sharma R, McMiller TL, Chen S, Klein AP, Pardoll DM, Topalian SL, Chen L. Colocalization of inflammatory response with B7-h1 expression in human melanocytic lesions supports an adaptive resistance mechanism of immune escape. Sci Transl Med. 2012; 4:127ra37.

13. Mamdani H, Induru R, Jalal SI. Novel therapies in small cell lung cancer. Transl Lung Cancer Res. 2015; 4: 533-44.

14. Planchard D, Le Péchoux C. Small cell lung cancer: new clinical recommendations and current status of biomarker assessment. Eur J Cancer. 2011; 47:S272-83.

15. Herbst RS, Soria JC, Kowanetz M, Fine GD, Hamid O, Gordon MS, Sosman JA, McDermott DF, Powderly JD, Gettinger SN, Kohrt HE, Horn L, Lawrence DP, et al. Predictive correlates of response to the anti-PD-L1 antibody MPDL3280A in cancer patients. Nature. 2014; 515:563-7.

16. Yang $\mathrm{CY}$, Lin MW, Chang YL, Wu CT, Yang PC. Programmed cell death-ligand 1 expression in surgically resected stage I pulmonary adenocarcinoma and its correlation with driver mutations and clinical outcomes. Eur J Cancer. 2014; 50:1361-9.

17. Chen TC, Wu CT, Wang CP, Hsu WL, Yang TL, Lou PJ, Ko JY, Chang YL. Associations among pretreatment tumor necrosis and the expression of HIF-1 $\alpha$ and PD-L1 in advanced oral squamous cell carcinoma and the prognostic impact thereof. Oral Oncol. 2015; 51:1004-10.

18. Velcheti V, Rimm DL, Schalper KA. Sarcomatoid lung carcinomas show high levels of programmed death ligand-1 (PD-L1). J Thorac Oncol. 2013; 8:803-5.

19. Chang YL, Yang CY, Lin MW, Wu CT, Yang PC. PD-L1 is highly expressed in lung lymphoepithelioma-like carcinoma: A potential rationale for immunotherapy. Lung Cancer. 2015; 88:254-9. 
20. Ishii H, Azuma K, Kawahara A, Yamada K, Imamura Y, Tokito T, Kinoshita T, Kage M, Hoshino T. Significance of programmed cell death-ligand 1 expression and its association with survival in patients with small cell lung cancer. J Thorac Oncol. 2015; 10:426-30.

21. Schultheis AM, Scheel AH, Ozretić L, George J, Thomas RK, Hagemann T, Zander T, Wolf J, Buettner R. PD-L1 expression in small cell neuroendocrine carcinomas. Eur J Cancer. 2015; 51:421-6.

22. Komiya T, Madan R. PD-L1 expression in small cell lung cancer. Eur J Cancer. 2015; 51:1853-5.

23. Song M, Chen D, Lu B, Wang C, Zhang J, Huang L, Wang X, Timmons CL, Hu J, Liu B, Wu X, Wang L, Wang J, et al. PTEN loss increases PD-L1 protein expression and affects the correlation between PD-L1 expression and clinical parameters in colorectal cancer. PLoS One. 2013; 8: e65821.

24. Borghael H, Paz-Ares L, Horn L, Spigel DR, Steins M, Ready NE, Chow LQ, Vokes EE, Felip E, Holgado E, Barlesi F, Kohlhäufl M, Arrieta $\mathrm{O}$, et al. Nivolumab versus Docetaxel in advanced nonsquamous non-small-cell lung cancer. N Engl J Med. 2015; 373:1627-39.

25. Brahmer J, Reckamp KL, Baas P, Crinò L, Eberhardt WE, Poddubskaya E, Antonia S, Pluzanski A, Vokes EE, Holgado E, Waterhouse D, Ready N, Gainor J, et al. Nivolumab versus Docetaxel in advanced squamous-cell non-small-cell lung cancer. N Engl J Med. 2015; 373:123-35.

26. Powles T, Eder JP, Fine GD, Braiteh FS, Loriot Y, Cruz C, Bellmunt J, Burris HA, Petrylak DP, Teng SL, Shen X, Boyd Z, Hegde PS, et al. MPDL3280A (anti-PD-L1) treatment leads to clinical activity in metastatic bladder cancer. Nature. 2014; 515:558-62.

27. Han L, Liu F, Li R, Li Z, Chen X, Zhou Z, Zhang X, Hu T, Zhang Y, Young K, Sun S, Wen J, Zhang M. Role of programmed death ligands in effective T-cell interactions in extranodal natural killer/T-cell lymphoma. Oncol Lett. 2014; 8:1461-9.

28. Yang CY, Lin MW, Chang YL, Wu CT, Yang PC. Programmed cell death-ligand 1 expression is associated with a favourable immune microenvironment and better overall survival in stage I pulmonary squamous cell carcinoma. Eur J Cancer. 2016; 57:91-103.

29. Jiang L, Zhao Z, Jiang S, Lin Y, Yang H, Xie Z, Lin Y, Long $H$. Immunological markers predict the prognosis of patients with squamous non-small cell lung cancer. Immunol Res. 2015; 62:316-24.

30. Chen YB, Mu CY, Huang JA. Clinical significance of programmed death-1 ligand-1 expression in patients with non-small cell lung cancer: A 5-year-follow-up study. Tumori. 2012; 98:751-5.

31. Ohigashi Y, Sho M, Yamada Y, Tsurui Y, Hamada K, Ikeda N, Mizuno T, Yoriki R, Kashizuka H, Yane K, Tsushima F, Otsuki N, Yagita H, et al. Clinical significance of programmed death-1 ligand-1 and programmed death-1 ligand-2 expression in human esophageal cancer. Clin Cancer Res. 2005; 11:2947-53.

32. Wu C, Zhu Y, Jiang J, Zhao J, Zhang XG, Xu N. Immunohistochemical localization of programmed death-1 ligand-1 (PD-L1) in gastric carcinoma and its clinical significance. Acta Histochem. 2006; 108:19-24.

33. Nomi T, Sho M, Akahori T, Hamada K, Kubo A, Kanehiro H, Nakamura S, Enomoto K, Yagita H, Azuma M, Nakajima Y. Clinical significance and therapeutic potential of the programmed death-1 ligand/programmed death-1 pathway in human pancreatic cancer. Clin Cancer Res. 2007; 13:2151-7.

34. Gao Q, Wang XY, Qiu SJ, Yamato I, Sho M, Nakajima Y, Zhou J, Li BZ, Shi YH, Xiao YS, Xu Y, Fan J. Overexpression of PD-L1 significantly associates with tumor aggressiveness and postoperative recurrence in human hepatocellular carcinoma. Clin Cancer Res. 2009; 15:971-9.

35. Hamanishi J, Mandai M, Iwasaki M, Okazaki T, Tanaka Y, Yamaguchi K, Higuchi T, Yagi H, Takakura K, Minato N, Honjo T, Fujii S. Programmed cell death 1 ligand 1 and tumor-infiltrating $\mathrm{CD} 8+\mathrm{T}$ lymphocytes are prognostic factors of human ovarian cancer. Proc Natl Acad Sci USA. 2007; 104:3360-5.

36. Schalper KA, Velcheti V, Carvajal D, Wimberly H, Brown J, Pusztai L, Rimm DL. In situ tumor PD-L1 mRNA expression is associated with increased TILs and better outcome in breast carcinomas. Clin Cancer Res. 2014; 20:2773-82.

37. Hino R, Kabashima K, Kato Y, Yagi H, Nakamura M, Honjo T, Okazaki T, Tokura Y. Tumor cell expression of programmed cell death-1 ligand 1 is a prognostic factor for malignant melanoma. Cancer. 2010; 116:1757-66. 